\title{
Spontaneous Release of Acetylcholine Affects the Physiological Nicotinic Responses of Rat Retinal Ganglion Cells in Culture
}

\author{
Stuart A. Lipton \\ Department of Neurology, The Children's Hospital and Program in Neuroscience, Harvard Medical School, Boston, \\ Massachusetts 02115
}

\begin{abstract}
Nictonic cholinergic responses have been previously documented in mammalian retinal ganglion cells. In the present study, dissociated retinal cells were densely plated and grown in a specific batch of rat serum. When held at negative potentials during whole-cell recording with a patch electrode, the retinal ganglion cells located close to presumptive cholinergic amacrine cells in these cultures were found to respond to acetylcholine (ACh; 20-200 $\mu \mathrm{M}$ ) with an apparent outward current in the presence of physiological salines on both sides of the membrane. Other nicotinic agonists (nicotine, carbachol) produced the same effect. Conductance measurements revealed that this apparent outward current was actually a decrease in a tonic inward current. Nicotinic antagonists such as $d$-turbocurarine $(10 \mu \mathrm{M})$ and dihydro- $\beta$ erythroidine $(20 \mu \mathrm{M})$, when applied in dishes that had never been exposed to exogenous ACh, produced a similar decrease in a tonic inward current. The reversal potential of the tonic current suppressed by ACh was similar to the nicotinic current previously studied in these central neurons. Furthermore, purified acetylcholinesterase was capable of modulating the tonic inward current of the retinal ganglion cells. Lowering an excised patch of muscle into dense areas of the retinal cultures activated nicotinic channels in the muscle membrane, indicating the presence of endogenous $\mathrm{ACh}$ in the culture fluid. Divalent cations such as $\mathrm{Co}^{2+}$ blocked the tonic inward current of retinal ganglion cells in these cultures. Finally, direct biochemical measurements indicated that low levels of endogenous ACh (on the order of 0.5 $\mu \mathrm{M}$ near putative cholinergic amacrine cells) were present in the retinal cultures. Taken together, these results show that $\mathrm{ACh}$ was being spontaneously released into these cultures, resembling at least to some degree the tonic leakage of $\mathrm{ACh}$ found in the intact retina. This concentration of $\mathrm{ACh}$ was capable of tonically depolarizing the membrane potential of retinal ganglion cells exposed to this dosage. This
\end{abstract}

\footnotetext{
Received Sept. 8, 1987; revised Dec. 17, 1987; accepted Feb. 8, 1988.

This work was supported by National Institutes of IIealth Grants NS00789, EY05477, and EY06087; NSF Grant BNS-8606145; and a grant from the National Society for Research to Prevent Blindness. I thank Elias Aizenman, Dinah Sah, and David Tauck for performing the biochemical assays for $\Lambda \mathrm{Ch}$; Jim Huettner, Elias Aizenman, and David Tauck for the immunofluorescence staining with ChAT antibody; Matthew Frosch for helpful discussions and computer programs; and Paul Harcourt, Micheal Phillips, and Beth Cahoon for excellent technical assistance.

Correspondence should be addressed to Stuart A. Lipton, M.D., Ph.D., Associate Professor of Neurology/Neuroscience, The Children's Hospital-G4, 300 Longwood Avenue, Boston, MA 02115.

Copyright (C) 1988 Society for Neuroscience $0270-6474 / 88 / 103857-12 \$ 02.00 / 0$
}

culture system allows the study of trophic effects of ACh on a central mammalian neuron in a precisely controlled extracellular environment.

$\Lambda$ cetylcholine (ACh) is thought to be one of the major neurotransmitters in the mammalian retina mediating excitation between specific classes of amacrine cells and ganglion cells (Masland and Ames, 1976; Ariel and Daw, 1982a, b; Masland et al., 1984b; Tauchi and Masland, 1984). ACh has been shown to be released from the intact retina in response to transients of light, both at onset and offset of stimulation (Masland and Livingstone, 1976; Massey and Neal, 1979; Masland et al., 1984a). In addition, there is a relatively large spontaneous release of ACh from the retina which is independent of the calcium concentration. Most of this calcium-independent release probably represents a nonquantal leakage (Masland et al., 1984a; Masland and Cassidy, 1987). This phenomenon, occurring in the mammalian CNS, may be similar to that seen at the neuromuscular junction (Katz and Miledi, 1977; for a review, see Tauc, 1982; Sun and Poo, 1985).

In the present study, we found evidence for the spontaneous release of $\mathrm{ACh}$ into the fluid bathing retinal cultures, in some sense resembling the findings in the intact retina. Two classes of experiments suggested this conclusion. First, patch-clamp recordings showed that an apparent outward current of retinal ganglion cells in culture could be induced by local microperfusion of ACh or nicotinic antagonists such as $d$-tubocurarine (dTC). Analysis of these findings revealed that the presumed outward current was actually a decrease in an inward current that had been activated by the tonic release of $\mathrm{ACh}$ into the medium. Furthermore, single cholinergic channels could be activated by this endogenous $\mathrm{ACh}$ using outside-out patches of muscle containing nicotinic receptors as an assay for detection (similar to the technique of Hume et al., 1983; Young and Poo, 1983). Second, using a tritiated choline precursor, it was possible to directly quantify very low levels of $\mathrm{ACh}$ in the culture fluid. A preliminary communication of parts of this work has been reported previously in abstract form (Frosch et al., 1986).

\section{Materials and Methods}

Preparation of cultures. Retinal cultures were prepared as described previously (Leifer et al., 1984; Lipton, 1986; Lipton and Tauck, 1987). Briefly, under general anesthesia a fluorescent dye (granular blue) was injected in situ into the superior colliculi of rat pups at ages postnatal day 5-12 (P5-12) for retrograde transport to the retinal ganglion cells over a $2 \mathrm{~d}$ period. The presence of dye permitted the unequivocal identification of the ganglion cells following dissociation of the retina using the enzyme papain. In previous studies the retinal ganglion cells were also labeled after dissociation using immunocytochemical techniques 
with monoclonal antibodies against Thy-1 (Leifer et al., 1984). The same population of retinal ganglion cells was identified by Thy-1 antibodies and by retrograde transport of fluorescent dye (Leifer et al., 1984), ensuring the reliability of either technique. For convenience, during the course of the present study the retrograde transport method was routinely used. The dissociated retinal cells were maintained in culture for a period of $1-3 \mathrm{~d}$ at $37^{\circ} \mathrm{C}$ for these experiments. The culture fluid consisted of minimum essential medium (GIBCO 320-1090) supplemented with methylcellulose $(0.7 \% \mathrm{wt} / \mathrm{vol})$, glutamine $(2 \mathrm{~mm})$, gentamicin $(1 \mu \mathrm{g} / \mathrm{ml})$, glucose $(16 \mathrm{mM})$, and rat serum $(5 \% \mathrm{vol} / \mathrm{vol})$. The serum was produced from albino (CD) rats by bleeding 25-50 retired breeders, heat-inactivating the serum at $56^{\circ} \mathrm{C}$ for $10 \mathrm{~min}$, and storing it at $-80^{\circ} \mathrm{C}$ until use. Approximately $1 \%$ of the dissociated retinal cells were identifiable as ganglion cells because of the fluorescent label. When plated on plain glass coverslips, about $15 \%$ of the ganglion cells were found as solitary neurons (not touching any other cells) and were spatially compact (5-20 $\mu \mathrm{m}$ in diameter and lacked processes; Leifer et al., 1984; Lipton and Tauck, 1987). These ganglion cells were used for the electrophysiological recordings.

Electrophysiology. Patch-clamp recordings were performed in the whole-cell and outside-out configurations (Hamill et al., 1981). The procedures for recording from rat retinal ganglion cells have been described previously (Lipton and Tauck, 1987). Immediately before a recording session, the incubation medium in which the cells were grown was replaced with a physiological saline solution based upon Hanks' salts (in $\mathrm{mm}$ ): $\mathrm{NaCl}, 137 ; \mathrm{NaHCO}_{3}, 1 ; \mathrm{Na}_{2} \mathrm{HPO}_{4}, 0.34 ; \mathrm{KCl}, 5.36$ $\mathrm{KH}_{2} \mathrm{PO}_{4}, 0.44 ; \mathrm{CaCl}_{2}, 2.5 ; \mathrm{MgSO}_{4}, 0.5 ; \mathrm{MgCl}_{2}, 0.5 ; \mathrm{HEPES}-\mathrm{NaOH}, 5$ glucose, 22.2; $\mathrm{pH} 7.2$; phenol red indicator, $0.001 \%$ (vol $/ \mathrm{vol})$. The recording dish contained a stainless-steel insert that limited the fluid volume to $100 \mu \mathrm{l}$, and the cells were continuously superfused with the physiological solution at a rate of $0.8 \mathrm{ml} / \mathrm{min}$. Ganglion cells were identified by brief fluorescence illumination while observed under high magnification $(500 \times)$ with an inverted microscope (IM 35, Zeiss).

Electrophysiological measurements were performed at $35-37^{\circ} \mathrm{C}$ with patch electrodes (3-5 M 2 ) utilizing the methods originally described by Hamill et al. (1981) and applied to rat retinal ganglion cells by Lipton and Tauck (1987). The internal side of the membrane was exposed to a solution which usually contained $140 \mathrm{mM} \mathrm{KCl}, 2 \mathrm{~mm} \mathrm{MgCl}, 1 \mathrm{mM}$ $\mathrm{CaCl}_{2}, 1.5 \mathrm{~mm}$ EGTA, and $10 \mathrm{~mm}$ HEPES-NaOH buffered at $\mathrm{pH} 7.2$. The internal $\mathrm{Ca}^{2+}$ concentration has been calculated to be $2 \times 10^{-7} \mathrm{M}$ (Caldwell, 1970). Internal potassium was at times substituted with cesium and tetraethylammonium ions (TEA) to suppress the $\mathrm{K}^{+}$currents (Lipton and Tauck, 1987). Other ionic substitutions are noted in the figure legends.

The current entering the patch electrode was led to an EPC-7 amplifier (List Electronic, F.R.G.). Holding and command potentials were generated by a digital-to-analog converter (Cheshire Data) interfaced to a PDP-11/23 or $11 / 73$ computer (Digital Equipment Corporation). The recorded currents were digitized with a 12 -bit, $125 \mathrm{kHz}$ analog-to-digital converter (model DT2782 DMA; Data Translation) and viewed both on an analog oscilloscope (model 5111A, Tektronix) and on a HewlettPackard digital display (model 1345A). The sampling rate was set at $0.25-3.3 \mathrm{kHz}$, and the signals were filtered accordingly (model 4302 , Ithaco with a Bessel frequency cut-off characteristic of $48 \mathrm{~dB} /$ octave). Data from records lasting many seconds in duration were commonly collected directly into computer memory and redisplayed using only every 16th point for ease of measurement. The additional points were useful for high temporal resolution, for example, of single channels. Data were stored on a 30-megabyte Winchester disk (model 880, Data System Design) and transferred to streaming tape (model LSI-50, Alloy Computer Products). The indifferent electrode was a $\mathrm{Ag} / \mathrm{AgCl}$ wire connected to the extracellular solution by a $2 \mathrm{M} \mathrm{KCl}$-agarose bridge; leakage currents, series resistance, and liquid junction potentials were corrected as described by Fenwick et al. (1982).

Outside-out patch recordings from myotubes were obtained in a fashion similar to that described by Hume et al. (1983) and Young and Poo (1983); these excised patches were used to detect the presence of ACh in the culture fluid. The myotube cultures were prepared from striated muscle in the hind-limbs of P1 rat pups essentially as described elsewhere (Puro et al., 1982; Yeh et al., 1983).

Local microperfusion of drugs. An efficient and rapid technique for presenting a drug to the cell under study was by pressure ejection from micropipettes placed in close proximity $(10 \mu \mathrm{m})$ to the cell. Conventional intracellular microelectrodes had their tips carefully broken under the microscope so that the resulting aperture was approximately $5 \mu \mathrm{m}$ in diameter. The application of air pressure to the "pneumatic" pipette was automatically controlled with the computer using software written in the Basic/23 language. The concentration of drugs listed in the figures is that in the microperfusion pipette, not accounting for possible dilution after pressure ejection.

Staining for choline acetyltransferase. A mouse anti-rat monoclonal antibody against choline acetyltransferase (ChAT) was used to label putative cholinergic amacrine cells in the retinal cultures. The antibody was prepared by Drs. Robert Baughman and Felix Eckenstein (Dept. of Neurobiology, Harvard Medical School). Retinal cells were grown in normal medium for $18 \mathrm{hr}$ and then fixed with a solution of $0.1 \mathrm{M}$ sodium phosphate with $4 \%$ paraformaldehyde- $15 \%$ picric acid. Picric acid had been previously prepared from an aqueous saturated solution. Fixed cells were incubated overnight with the mouse anti-ChAT IgG in a Trisbuffered solution (TBS) containing $2 \%$ BSA, $20 \%$ normal horse serum, $0.5 \%$ Triton $\mathrm{X}-100$, and $0.02 \%$ azide. Cells were then rinsed with TBS and incubated with rabbit anti-mouse IgG for $1 \mathrm{hr}$ in a TBS solution containing $10 \%$ rat serum, $10 \%$ rabbit serum, and $0.1 \%$ Triton $\mathrm{X}-100$. Following this step, the cells were incubated in mouse PAP for $1 \mathrm{hr}$ in a TRS solution. Incubations in secondary antibody and PAP were repeated and the peroxidase was reacted with DAB for approximately 2 min, until staining became apparent.

Measurement of $\mathrm{ACh}$. To measure endogenous $\mathrm{ACh}$, the "radiolabeled-precursor-loading-technique" followed by high-voltage paper electrophoresis (to separate the precursor ${ }^{3} \mathrm{H}$-choline from the released product ${ }^{3} \mathrm{H}-\mathrm{ACh}$ ) was utilized (Hildebrand et al., 1971; Furshpan et al., 1986). Eighteen-hour-old dissociated retinal cultures were rinsed and incubated with choline-deficient medium (Hanks' solution) for $10 \mathrm{~min}$ at $37^{\circ} \mathrm{C}$. The cells were then incubated for $4 \mathrm{hr}$ at $37^{\circ} \mathrm{C}$ in $75 \mu \mathrm{l}$ of growth medium (without methylcellulose) containing $0.18 \mu \mathrm{Ci} / \mu \mathrm{l}$ of ${ }^{3} \mathrm{H}$-choline $(80 \mathrm{Ci} / \mathrm{mmol}$; New England Nuclear) and a total choline concentration of $100 \mu \mathrm{M}$ (labeled + unlabeled). Within this time period the specific activity of the ACh pool within retinal cells has come to equilibrium (Masland and Cassidy, 1987). The radioactive medium was removed after the incubation period, and the cells were rinsed 3 times with modified Hanks' buffer. Cells were then incubated for $3 \mathrm{hr}$ at $37^{\circ} \mathrm{C}$ in $75 \mu \mathrm{l}$ of a $10 \mu \mathrm{M}$ neostigmine bromide (Sigma) solution of growth medium (without methylcellulose). Samples from 3 dishes were pooled, dried with nitrogen gas at $4^{\circ} \mathrm{C}$, and resuspended in $20 \mu$ lof electrophoresis buffer (a $2 \%$ formic acid and $8 \%$ acetic acid aqueous solution which contains $2 \mathrm{mg} / \mathrm{ml}$ choline and $2 \mathrm{mg} / \mathrm{ml} \mathrm{ACh}, \mathrm{pH} 1.9)$. The resulting samples were spotted onto $3 \mathrm{~mm}$ Whatman paper for high-voltage electrophoresis (45 min at $2500 \mathrm{~V}$ ). Following electrophoretic separation of ${ }^{3} \mathrm{H}$-choline and ${ }^{3} \mathrm{H}$-ACh, their positions were determined by iodine vapor staining of unlabeled carrier $\mathrm{ACh}$ and choline. The stained spots were cut from the paper and the radioactivity extracted with $0.01 \mathrm{~N}$ $\mathrm{HCl}$, mixed with Aquasol-2 (New England Nuclear) and counted in a liquid scintillation counter. Radioactive counts per minute were then converted into concentration of ${ }^{3} \mathrm{H}$-ACh utilizing the specific activity of the precursor.

Staining for acetyicholinesterase. The procedure used to label the enzyme acetylcholinesterase (AChE) was originally developed by Koelle (1954) and then modified by Mesulam and Dichter (1981) and by Delfs et al. (1984) for use in CNS cells in tissue culture. Retinal cultures were first rinsed in physiological saline and then fixed at room temperature in $4 \%$ paraformaldehyde for $10-30 \mathrm{~min}$ followed by $5 \%$ dimethyl sulfoxide for $30 \mathrm{~min}$. The coverslips containing the retinal cultures were next incubated overnight in $4 \mathrm{~mm}$ acetylthiocholine, $10 \mathrm{~mm}$ glycine, and $2 \mathrm{~mm}$ copper sulfate in $50 \mathrm{~mm}$ sodium acetate (pH 5.0) at $4^{\circ} \mathrm{C}$. The addition of $0.2 \mathrm{~mm}$ ethopropazine to this mixture inhibited nonspecific cholinesterases. AChE staining developed at room temperature in 40 $\mathrm{mm}$ sodium sulfide $\left(\mathrm{pH} 7.8,2^{1 / 2} \mathrm{~min}\right)$ and intensified with incubation in $1 \%$ silver nitrate $(2 \mathrm{~min})$.

\section{Results}

\section{Patch-clamp recordings}

Effects of nicotinic agonists in cultures lacking endogenous $A C h$

Virtually all rat retinal ganglion cells in culture for $5 \mathrm{hr}$ to $3 \mathrm{~d}$ responded to local microperfusion of $\mathrm{ACh}(n=214)$. When voltage-clamped with a patch electrode in the whole-cell mode to negative holding potentials (e.g., to the resting potential of 
$-60 \mathrm{mV}$; Lipton and Tauck, 1987), $20 \mu \mathrm{M}$ ACh produced an inward current (Fig. 1). In the presence of continuous agonist, this current desensitized with an exponential time course. Previous work has shown that the $\mathrm{ACh}$-induced whole-cell current, as well as the underlying single-channel events, is carried by cations, has a linear current-voltage relationship that reverses in polarity near $0 \mathrm{mV}$ in the presence of physiological concentrations of cations, and exhibits responses to pharmacological agents that are nicotinic in character (Lipton et al., 1987). The pharmacologic properties of the central nicotinic receptor mediating these responses are similar to those of autonomic ganglia in the PNS but different from those at the neuromuscular junction. For example, ACh-induced currents were blocked by low doses $(2-10 \mu \mathrm{M})$ of the classical "ganglionic" antagonists hexamethonium and mecamylamine, as well as by dTC and dihydro$\beta$-erythroidine (the latter 2 do not discriminate clearly between ganglionic and neuromuscular junction receptors). Furthermore, treatment with the potent neuromuscular blocking agent $\alpha$-bungarotoxin $(10 \mu \mathrm{M})$ did not affect the cholinergic responses of these cells, while neuronal-bungarotoxin $(0.2 \mu \mathrm{M})$, a neural nicotinic receptor antagonist formerly called toxin $\mathrm{F}$, readily abolished agonist-induced currents (Lipton et al., 1987). Although all retinal ganglion cells responded to $\mathrm{ACh}$, carbachol, or nicotine, the magnitude of the response, presumably reflecting the number of cholinoreceptive sites, varied widely from cell to cell (range: $6-100 \mathrm{pA}$ at a holding potential of $-80 \mathrm{mV}$; Lipton et al., 1987). Furthermore, this prior work demonstrated that an appreciable muscarinic effect could not be observed in these cells, at least under whole-cell recording conditions.

\section{Responses to nictonic agonists in culture dishes containing spontaneous release of $\mathrm{ACh}$}

In other experiments, the culture dishes contained more densely plated cells $\left(>2 \times 10^{5}\right.$ cells $/$ dish $)$ and a different batch of rat scrum. The culture fluid of thesc dishes was later found to have detectable endogenous levels of $\mathrm{ACh}$ using the criteria stated below. Under these conditions, the application of ACh (20-200 $\mu \mathbf{M})$ or nicotine $(40 \mu \mathbf{M})$ to retinal ganglion cells located near clusters of other retinal cells (within $20 \mu \mathrm{m}$ ) resulted in an at first unexpected and surprising result-an apparent outward rather than inward current at negative holding potentials (Figs. 2 and $6 A ; n=136)$. Similar to the inward nicotinic current described above, the amplitude of the presumptive outward current varied widely among cells voltage-clamped at the same negative holding potential (Fig. 2, $A$ and $B$ ). In contrast, wholecell patch-clamp recordings from retinal ganglion cells in the same culture but located at some distance (i.e., $>200 \mu \mathrm{m}$ ) from the other cells in the dish exhibited the same inward current at negative holding potentials as the ganglion cells in the previous experiments described in Figure $1(n=12)$. One notion that these results are consistent with is that there is spontancous release of low levels of $\mathrm{ACh}$ into the culture fluid from cholinergic amacrine cells, resulting in a tonic activation of nicotinic receptor/channels in ganglion cells that are located nearby. These nicotinic receptors then desensitize with the application of additional exogenous $\mathrm{ACh}$, producing an apparent outward current as the tonic inward nicotinic current is turned off. If this formulation were correct, then one might expect that if retinal cells releasing $\mathrm{ACh}$ were located very close to ganglion cells, this would produce complete desensitization of the response. Indeed, this prediction was borne out; occasionally, retinal ganglion cells

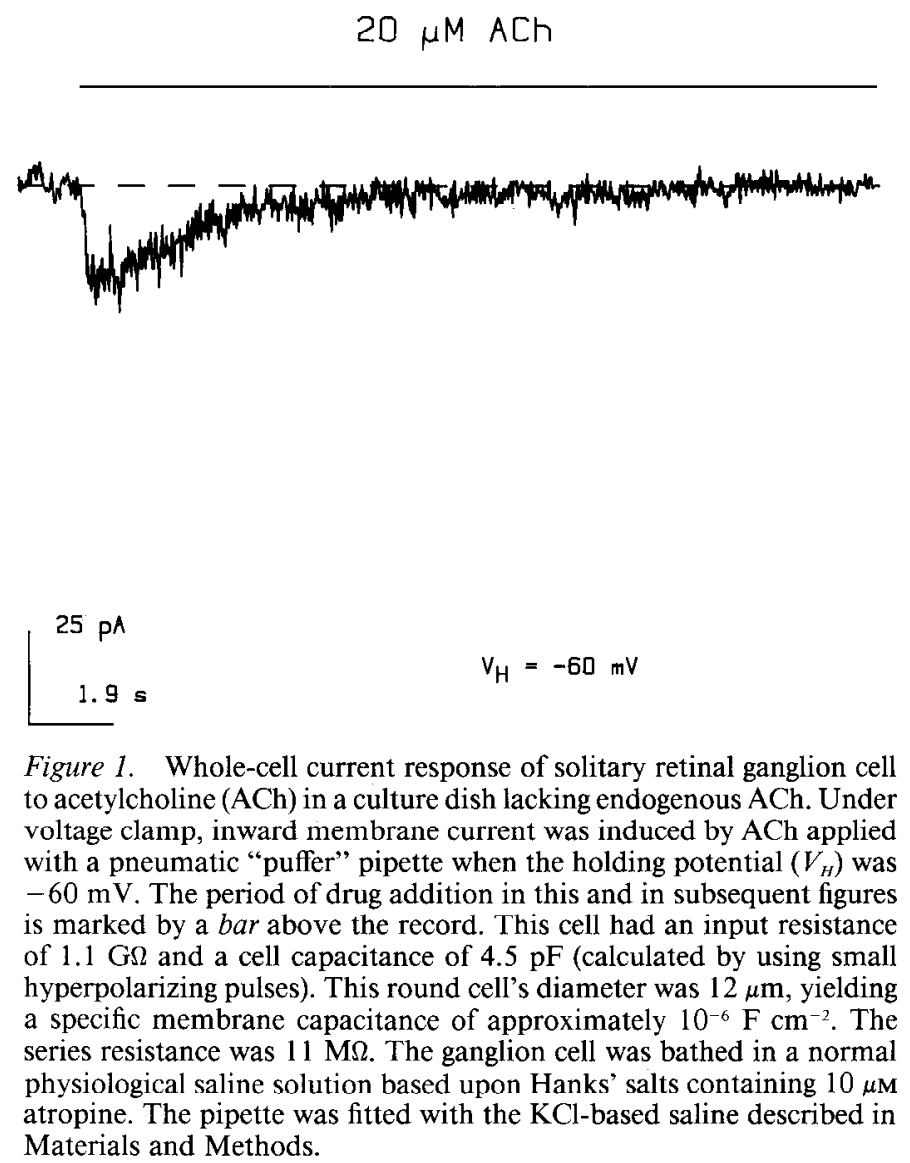

located even closer $(<5 \mu \mathrm{m})$ to clusters of other retinal cells exhibited no response to exogenous $\mathrm{ACh}(n=38)$. The lack of response was probably not due simply to a lack of nicotinic receptors. Recall from the foregoing results that all retinal ganglion cells in less dense cultures incubated in a different batch of serum responded to local microperfusion of ACh with an inward current at negative holding potentials, indicating that all of these neurons contained nicotinic receptors.

The hypothesis presented in the previous paragraph concerning the tonic release of $\mathrm{ACh}$ makes several other predictions, all of which are testable, as discussed below. For example, the apparent outward current induced by ACh would actually represent a decrease in the tonically activated inward current. Thus, this current should be accompanied by a decrease rather than an increase in membrane conductance. Figure 3 shows that in the presence of $\mathrm{ACh}$ the current responses to small hyperpolarizing pulses decreased in magnitude, indicating a decline in membrane conductance from Ohm's law. Thus, under these circumstances the addition of exogenous $\mathrm{ACh}$ did indeed result in a decrease in conductance.

\section{Nicotinic antagonists produce an apparent outward current}

Even if one were to accept at this juncture that $\mathrm{ACh}$ was present in the culture fluid of these dishes, how do we know that it is not the artificial result of a "leaky" micropipette containing ACh for pressure ejection? This possibility was eliminated by the following experiments. Pneumatic ejection micropipetles containing the nicotinic antagonists dTC $(10 \mu \mathrm{M})$ or dihydro- $\beta$ erythroidine ( $\mathrm{Dh} \beta \mathrm{e}, 20 \mu \mathrm{M})$ were lowered into culture dishes that were virgin with respect to exposure to agonist-containing 


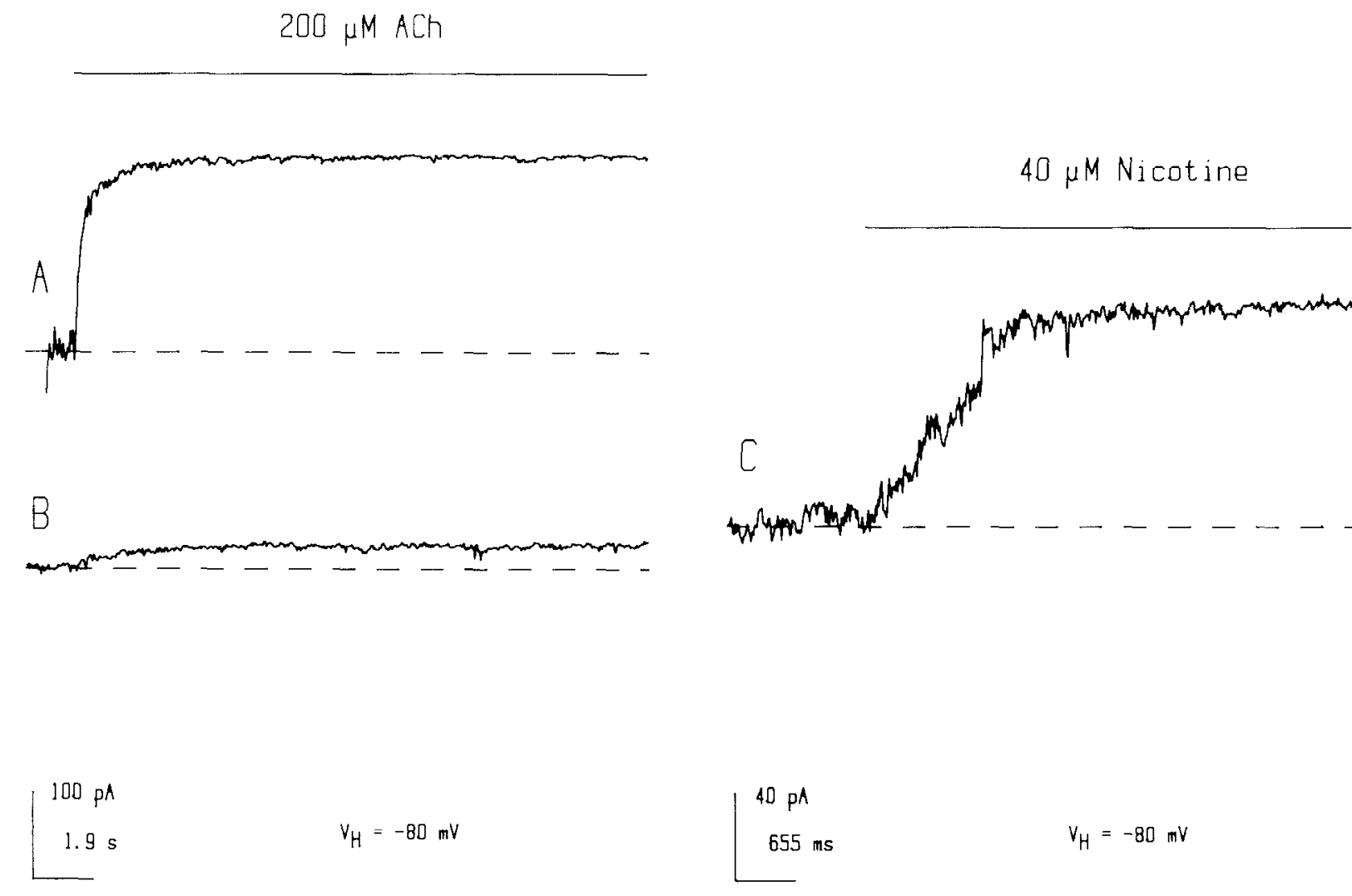

Figure 2. Effect of endogenous $\mathrm{ACh}$ on responses to exogenous $\mathrm{ACh}$ or nicotine. Drugs were applied by pressure ejection during whole-cell recordings. $A$ and $B$ illustrate the wide range of response magnitudes of apparent outward current to the application of $A C h$ in different retinal ganglion cells. $C$ shows the response of a third ganglion cell to nicotinc. The solutions wcre the samc as in Figure 1 except without atropine in the bath. The holding potential was $-80 \mathrm{mV}$ in each case.

pipettes. Under these conditions, local microperfusion with either dTC or Dhße onto retinal ganglion cells located near clusters of other retinal cells produced an apparent outward current in the ganglion cells (Fig. 4). These results are consistent with the notion that a low level of endogenous ACh was present in the medium near these ganglion cells and that the antagonists blocked the tonic activation of nicotinic receptors on the ganglion cells. It is noteworthy that, in less dense cultures incubated in a different batch of serum (and therefore lacking ACh by the criteria stated below), application of these nicotinic blockers never produced outward currents such as these (Lipton et al., 1987).

\section{Biphasic and triphasic responses to $A C h$}

If there is indeed an endogenous low level of $\mathrm{ACh}$ in these cultures due to spontaneous release, then one would be surprised if in at least some cases the addition of a large exogenous pulse of $\mathrm{ACh}$ provoked only a desensitization, not preceded by activation (resulting in an inward current when the cell is voltageclamped to negative holding potentials). Activation by the application of exogenous ACh would come about if the endogenous ACh level near a particular ganglion cell were high enough to partially but not completely activate all of the nicotinic channels. Thus, with local microperfusion of a high concentration of $\Lambda \mathrm{Ch}$ from the pressure ejection pipette, the remaining nicotinic channels would at first be activated (producing an inward current), and subsequently, following activation, all of the nicotinic channels on the ganglion cell would desensitize as the high level of ACh reached its peak concentration at the receptors. Such biphasic responses were occasionally observed in recordings from retinal ganglion cells that were located near other retinal cell types in these cultures $(n=4)$. Figure $5 A$ shows an example of this phenomenon.

Other retinal ganglion cells might be exposed to tonic levels of ACh that activated nearly the full complement of their nicotinic channels. In that case the expected response to a large bolus of exogenous $\mathrm{ACh}$ would consist of immcdiate desensitization. The responses in Figure 2 might represent examples of this effect. An alternative explanation for the lack of inward current preceding the desensitization might be that the delivery rate of a high concentration of exogenous $\mathrm{ACH}$ from the pipette was sufficiently swift that the preceding inward current could not be visualized at the recording bandwidth. For the reasons described below, under these conditions, however, an "oversheot" of inward current might occur when the pressure ejection pipette was switched off. Overshoot of this kind was observed as shown in Figure $5 B$, which demonstrates the response and subsequent course of membrane current when a high concentration of $\mathrm{ACh}$ was applied to a retinal ganglion cell. This finding is consistent with the notion that a high concentration of exogenous $\mathrm{ACh}$ leads to receptor desensitization, and, as the pressure ejection pipette is turned off and the concentration of $\mathrm{ACh}$ begins to fall, an intermediate dose of $\mathrm{ACh}$ reaches the receptors and produces a maximal activation of the channels. The concentration of exogenous ACh then continues to fall, and the current level returns to a baseline of tonic activation of nicotinic channels (but not at the maximal level) by the endogenous ACh.

Some retinal ganglion cells exhibited a combination of the effects seen in Figure 5, $A$, and $B$. The resulting response to 


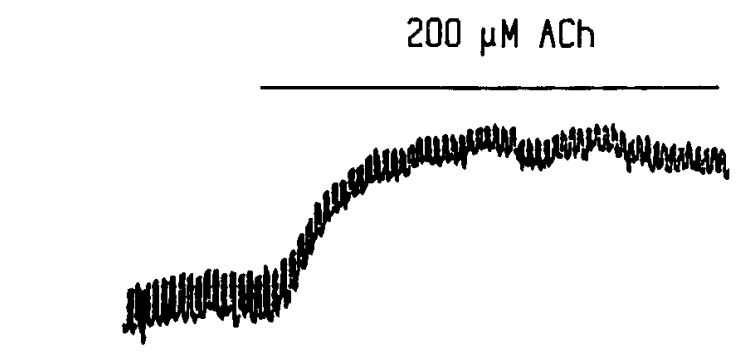

$$
\begin{aligned}
& 20 \mathrm{pA} \\
& 7.1 \mathrm{~s}
\end{aligned}
$$$$
V_{H}=-80 \mathrm{nV}
$$

Figure 3. Conductance measurement during exogenous application of $\mathrm{ACh}$ in a culture dish containing endogenous $\mathrm{ACh}$ in the culture fluid. During a whole-cell recording from a retinal ganglion cell that was voltage-clamped at $-80 \mathrm{mV}, 10 \mathrm{mV}$ hyperpolarizing pulses were administered. The current response to these pulses decreased in size when $200 \mu \mathrm{M}$ ACh was applied by pressure ejection from a micropipette. Thus, the application of exogenous ACh led to a decrease in membrane conductance. This result is consistent with the interpretation that exogenous ACh produced a decrease in a spontaneous inward current that was induced by an endogenous "leak" of ACh. The exogenous ACh possibly resulted in a decrease in inward current because of desensitization. The bath and pipette solutions were the same as in Figure 2.

application of $\mathrm{ACh}$ was a triphasic current, first inward (representing maximal activation of the channels), then outward (produced by receptor densensitization), and then inward again when the microperfusion pipette is switched off (provoked by a falling level of ACh which no longer produces desensitization but instead a maximal or near maximal activation). As expected, under current-clamp these responses were composed of depolarization followed by hyperpolarization and a final depolarization which subsequently repolarizes to the original baseline (not illustrated). In summary, the presence or absence of the early inward component of the current in these cells is possibly related to the rapidity of the application of $\mathrm{ACh}$ from the pressure pipette and thus the amount of time necessary for a high concentration of exogenous ACh to reach the receptors. Another interpretation of these data, however, is tenable. There is good evidence suggesting that $A C h$ receptors require 2 molecules of $\mathrm{ACh}$ for receptor activation, and some models postulate that receptors can be desensitized without being activated. Thus, it is also possible that $\mathrm{ACh}$ produced a decrease in inward current not preceded by an increase (as in Figs. 2 and $5 B$ ) because of desensitization without prior activation of all of the available receptors.

\section{Current-voltage relationship and ionic selectivity of the responses to $A C h$}

Previously it has been shown that under culture conditions lacking substantial levels of endogenous $\mathrm{ACh}$, both the whole-cell and single-channel nicotinic responses possess approximately lincar current-voltage $(I-V)$ relationships in the voltage range of -80 to $+40 \mathrm{mV}$ (Lipton et al., 1987). Further, the reversal potential of these $I-V$ curves indicates that the channels mediating the responses are most likely permeated by cations (Lipton et al., 1987). These results are similar to those obtained for nicotinic channels in embryonic muscle (Hamill and Sakmann, 1981) and in adrenal chromaffin cells (Fenwick et al., 1982).

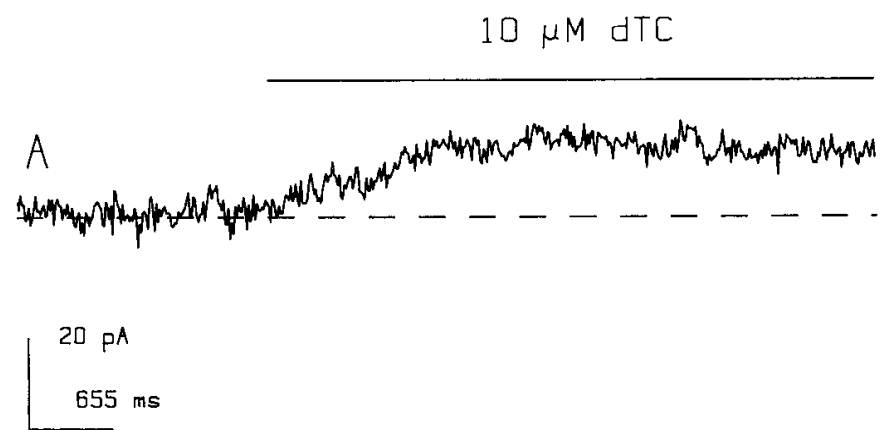

$20 \mu \mathrm{M}$ Dh $\mathrm{Be}$

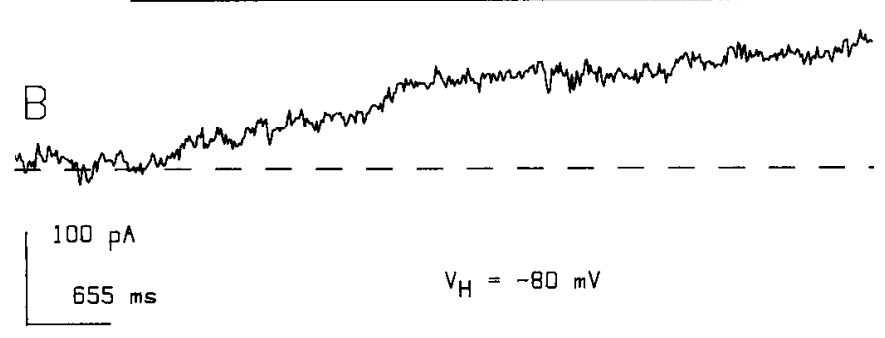

Figure 4. Effect of endogenous ACh on responses to exogenous nicotinic antagonists. $A, d$-Tubocurarine (dTC, $10 \mu \mathrm{m}$ ) was appied via presure ejection to a retinal ganglion cell in a dish that had not been exposed to an exogenous nicotinic agonist. An apparent outward current, which actually represented a decrease in a tonic inward current, was evoked. $B$, Similar result was obtained in another dish when dihydro$\beta$-erythroidine $(\mathrm{Dh} \beta \mathrm{e}, 20 \mu \mathrm{M})$ was applied to a ganglion cell. In both cases the ganglion cells were held at $-80 \mathrm{mV}$; the bath and pipette solutions were the same as in Figure 2.

The present experiments were designed to generate the $I-V$ relationship of the conductance suppressed by $\mathrm{ACh}$ under conditions fostering the release of $\mathrm{ACh}$ into the culture fluid. If this ACh-induced current were truly produced by the desensitization of a tonically activated nicotinic current, then the $I-V$ relationship should be similar to that obtained by activation of nicotinic channels in the absence of endogenous ACh. This was found to be the case (Fig. 6). In other words, the same conductance was affected by densensitization as by activation, and the $I-V$ relationship served as an identifying fingerprint of the conductance. Figure $6 A$ shows a family of currents induced by ACh in a culture containing endogenous levels of $\mathrm{ACh}$ by the criteria stated below. The current appears outward at negative holding potentials and inward at positive potentials. In Figure $6 B$ the $I-V$ relationship reveals that the current reverses in polarity near $0 \mathrm{mV}$ in the presence of a CsCl-based solution in the patch pipette and a Na-saline in the bath (see Materials and Methods for composition). Similar relations were obtained for other ganglion cells when the pipette contained Cs aspartate or Cs acetate substituted for $\mathrm{CsCl}$, suggesting selectivity for cations. Thus, it appears that the same conductance that was activated by local microperfusion of $\mathrm{ACh}$ in cultures lacking endogenous $\mathrm{ACh}$ was being suppressed (due to desensitization) in cultures presumably containing ACh.

\section{Nonresponsive cells respond in the presence of $A C h E$}

As previously mentioned, a number of retinal ganglion cells located very close to other retinal cells, which were presumably releasing $\mathrm{ACh}$ (see below), did not respond to the application of exogenous ACh. Since virtually all ganglion cells in cultures lacking endogenous $\mathrm{ACh}$ respond to the addition of $\mathrm{ACh}$ (Lipton 

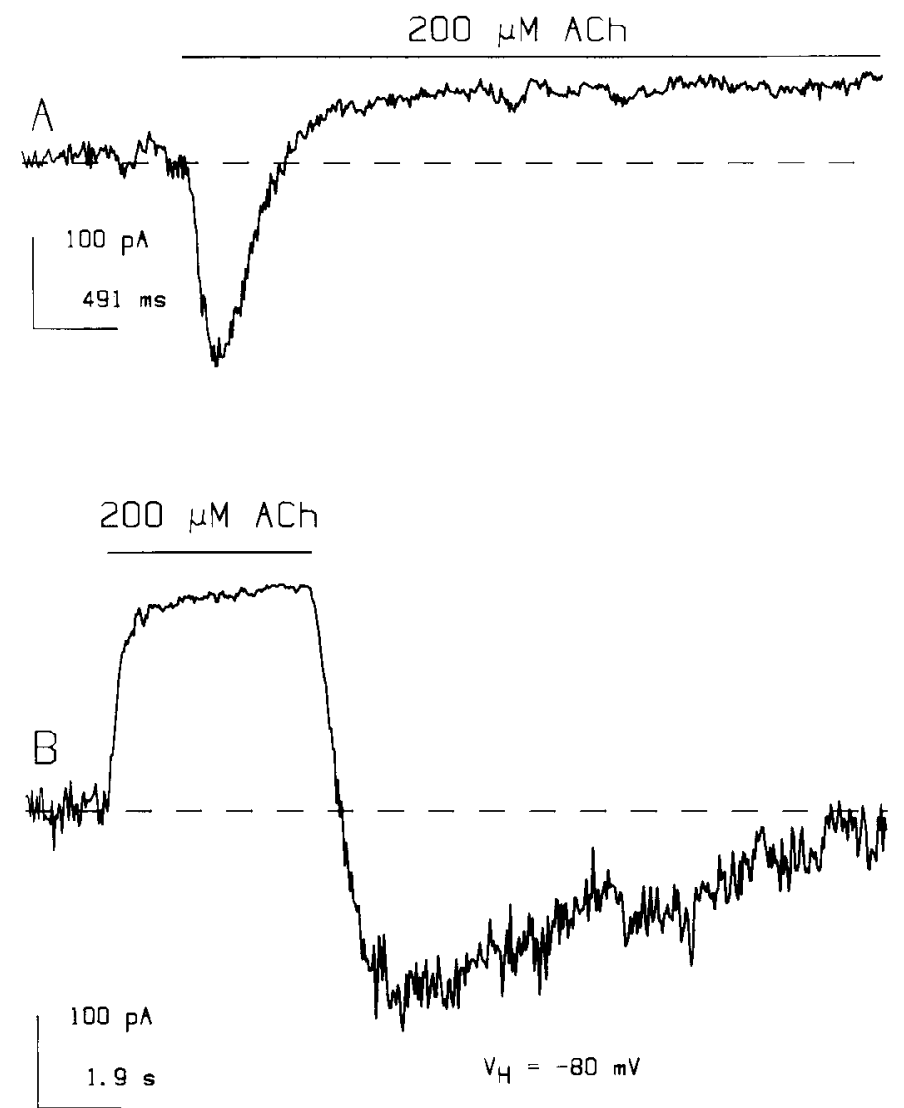

Figure 5. Biphasic current responses to exogenous ACh of retinal ganglion cells in culture dishes with endogenous ACh. $A$, Application of ACh $(200 \mu \mathrm{M})$ elicited an inward and then an outward current. $B$, In another cell in a different dish, application of ACh $(200 \mu \mathrm{M})$ resulted in an outward current and a less noisy trace during the period of addition; following the cessation of the application, an inward current developed that overshot the original level before returning to baseline. See text for interpretation of these results. In both cases the ganglion cells were held at $-80 \mathrm{mV}$; the bath and pipette solutions were the same as in Figure 2.

et al., 1987), it had been postulated that the nonresponsive ganglion cells were desensitized by the $\mathrm{ACh}$ that was being released in close proximity to them.

This supposition would predict that the addition of $\mathrm{AChE}$, to effect the enzymatic breakdown of some of the endogenous $\mathrm{ACh}$, should make the ganglion cell responsive to exogenous cholinergic agents. Figure 7 is an example of such an experiment. In this case, the cell did not respond to the application of 40 $\mu \mathrm{M}$ carbachol (CCh) or $\Lambda \mathrm{Ch}$ (not illustrated). Then, $5 \mathrm{U} / \mu \mathrm{l}$ of a purified preparation of AChE (Boehringer-Mannheim) was applied by a third pressure ejection pipette. The addition of $\mathrm{AChE}$ was titrated to yield the largest inward current by moving the pressure ejection pipette toward and away from the cell sealed to the recording patch electrode. In this manner it was possible to activate the maximum number of nicotinic channels by the remaining endogenous $\mathrm{ACh}$. This maneuver was performcd bccause it was then possible to predict that the application of any additional exogenous nicotinic agonists should result in receptor desensitization once again, provided the applied agonist were not broken down by the AChE. Consistent with this prediction, when a nonhydrolyzable agonist, $\mathrm{CCh}$, was applied, an apparent outward current was encountered that reached the original base- line, presumably duc to receptor desensitization (Fig. 7). Note that the noise in the record increased upon application of $\mathrm{AChE}$ and decreased in the presence of $\mathrm{CCh}$, compatible with this interpretation. Subsequently, an equimolar concentration of $\mathrm{ACh}$ was applied and resulted in a smaller apparent outward current. Although ACh is more potent than carbachol, its smaller response magnitude is consistent with its susceptibility to AChE. This experiment, in conjunction with the foregoing results, strongly suggested the presence of endogenous levels of ACh in these cultures.

The experiments of Figures 2-7 have been provisionally interpreted as if all of the actions of ACh were localized to the isolated, voltage-clamped retinal ganglion cells. However, if ACh receptors are also present on neighboring cells, then exogenous $\mathrm{ACh}$ application might modulate endogenous $\mathrm{ACh}$ release; in that case, desensitization thought to be due to the exogenous ACh could have an alternative explanation. For example, regulation of the endogenous release of ACh or another substance affecting the action of $\mathrm{ACh}$ on ganglion cells might occur by binding of exogenous ACh to receptors on neighboring cells. Then, the release of endogenous ACh and/or an endogenous modulator of ACh activity might be responsible for the subsequent desensitization of the receptors on the retinal ganglion cells. In any event, whatever the exact mechanism of action of the exogenously applied $\mathrm{ACh}$, all of the evidence supports the interpretation that endogenous $\mathrm{ACh}$ was released into the culture fluid.

\section{Outside-out muscle patches as ACh detectors}

All of the above evidence for endogenous ACh in these dense cultures is internally consistent, but I sought an independent line of reasoning based upon previous work with well-characterized nicotinic receptors in muscle. Such an approach is possible using an outside-out patch of muscle which contains nicotinic receptors as an ACh detector or "sniffer" pipette (originally described by Hume et al., 1983; Young and Poo, 1983). These workers used this technique to provide evidence for the spontaneous leak of $\mathrm{ACh}$ from developing neuromuscular synapses; the method is used here to demonstrate a similar release in these mammalian CNS cultures. A chard of glass from a myotube culture was transferred into the retinal culture dish just before the recording session. An outside-out patch of muscle was formed and monitored for activity far away from the retinal cells. If the patch was silent, it was then lowered into the area of clusters of retinal cells at which point single-channel events were observed (Fig. $8 A$ ). Single-channel activity was especially prominent in close proximity $(<20 \mu \mathrm{m})$ to retinal cells that had a profuse outgrowth of small processes (see below for the possible relationship of this morphology to the cholinergic amacrine cells). These channels were of similar conductance to those previously reported for nicotinic channels in muscle; in addition, the fact that the channels were desensitized by the application of $20 \mu \mathrm{M}$ ACh (Fig. 8B) indicates that they were affected by ACh and not by another substance such as ATP (for a discussion of this topic, see Hume and Honig, 1986). The single-channel data from excised patches of muscle represent an independent assay for the spontaneous release of $\mathrm{ACh}$ in these cultures. Outside-out patches from retinal ganglion cells were also formed in an attempt to detect ACh by single-channel activity, but this experiment was inconclusive because $>90 \%$ of the patches did not contain ACh receptors, signifying an extremely low density of receptors in ganglion cell membrane (Lipton et al., 1987). 


\section{peak current suppressed by ACh}

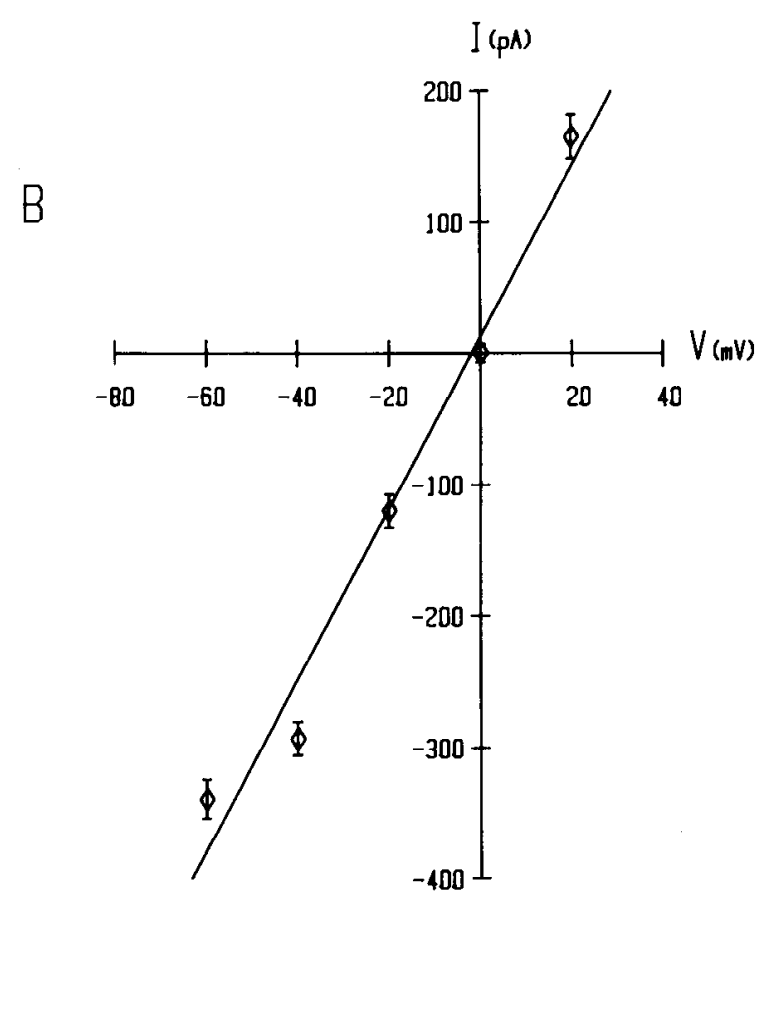

Figure 6. Current-voltage $(I-V)$ relationship obtained during the response of a ganglion cell to exogenous ACh (20 $\mu \mathrm{M})$ in a dish containing endogenous ACh. $A$, Membrane current responses during whole-cell recording of a ganglion cell held at various potentials. The traces were leaksubtracted to superimpose their initial values prior to the addition of ACh. The bath contained Hanks' solution; the pipette-filling solution had Cs acetate $(120 \mathrm{~mm})$ and TEA acetate $(20 \mathrm{~mm})$ substituted for $140 \mathrm{mM} \mathrm{KCl}$. $B$, Peak current of the responses in $A$ and additional responses from the same cell plotted versus the holding potential at which they were observed. The resulting $I-V$ curve is approximately linear and has a reversal potential of $-1.95 \mathrm{mV}$. The line, fitted by least-squares, has a coefficient of correlation $\left(r^{2}\right)$ of 0.9878 .

\section{Quantal or nonquantal nature of the ACh release-effect of cobalt and magnesium}

Several experiments were designed to determine the nature and the source of the presumptive spontaneous leak of ACh that was apparently contributing to an endogenous level of ACh in the retinal culture fluid. Some of these studies arc considered in the biochemical experiments below. The question of quantal or nonquantal release is taken up here. Previous experiments in this preparation have shown that the addition of a high concentration of $\mathrm{Mg}^{2+}$ (nominally $20 \mathrm{~mm}$ ) with low $\mathrm{Ca}^{2+}(0.2 \mathrm{~mm}$ ) will block synaptic activity and thus quantal release (Lipton, 1986); alternatively, $3 \mathrm{~mm} \mathrm{Co}^{2+}$ will block $\mathrm{Ca}^{2+}$ current (Lipton and Tauck, 1987) and result in the block of quantal release. Unfortunately, neither of these procedures will distinguish between quantal and nonquantal release in our cultures because the presence of these divalent cations, in addition to blocking presynaptic quantal release, also act as nicotinic channel blockers. This postsynaptic effect of the divalent ions is similar to that seen at the neuromuscular junction (Adams et al., 1980). An example of this nicotinic blocking effect by $\mathrm{Co}^{2+}$ is shown in Figure 9A: In a ganglion cell previously shown to respond to $\mathrm{ACh}$ with an apparent outward current at $-60 \mathrm{mV}$ (as in Fig. 2), $\mathrm{Co}^{2+}$ (3 mM) elicited a response of comparable magnitude ( $n$ $=6$ ). The current responses to $\mathrm{Co}^{2+}$ at other holding potentials $(-30,0,+30 \mathrm{mV})$ are also illustrated. In the presence of $\mathrm{Co}^{2+}$, $\mathrm{ACh}$ no longer produced a clear effect at any voltage $(n=4)$.

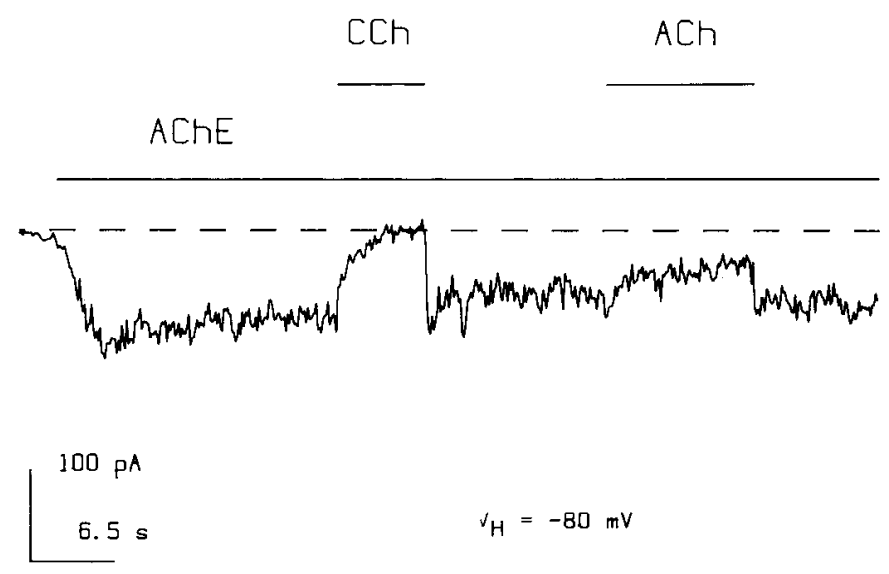

Figure 7. Effect of acetylcholinesterase (AChE) on the responses of a retinal ganglion cell to cholinergic agonists. AChE $(5 \mathrm{U} / \mathrm{ml}$, purified enzyme preparation from Boehringer-Mannheim) was applied by a pneumatic pipette to a cell that had not previously responded to ACh $(40 \mu \mathrm{M})$. The cell immediately displayed an inward current and subsequently appeared to desensitize when carbachol $(\mathrm{CCh} ; 40 \mu \mathrm{M})$ was applied. The effect of ACh $(40 \mu \mathrm{M})$ was less dramatic (see text for discussion). The pipette and bath solutions were the same as in Figure 2. 
A

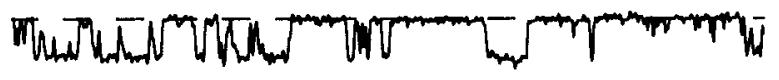

B

$20 \mu M A C h$

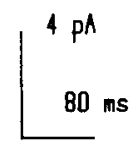

$$
V_{H}=-10 \mathrm{mV}
$$

Figure 8. Monitoring endogenous ACh in a retinal culture dish using an outside-patch of muscle. An outside-out patch of miuscle exhibited an increase in channel activity when placed in close proximity to a presumptive cholinergic amacrine cell $(A)$; these channels appeared to be nicotinic from their amplitude and permeation characteristics. The single-channel activity abated when a high concentration $(20 \mu \mathrm{M})$ of $\mathrm{ACh}$ was applied by pressure ejection $(B)$. This decrement in single-channel activity probably arose because of desensitization induced by the exogenous ACh. The pipette and bath solutions were the same as in Figure 2.

The $I-V$ relation for the current affected by $\mathrm{Co}^{2+}$ is plotted in Figure $9 B$ and is similar to that seen for ACh (Fig. 6). The most likely interpretation of these results is that $\mathrm{Co}^{2+}$ was blocking the nicotinic channel. Thus, $\mathrm{ACh}$ could no longer exert an effect since the channels were already blocked prior to $\mathrm{ACh}$ application as in Figure $9 \mathrm{~A}$.

\section{Immunohistochemical and biochemical experiments}

\section{Staining for choline acetyltransferase}

Two specific populations of amacrine cells in the intact mammalian retina appear to be cholinergic (Famiglietti, 1983; Masland et al., 1984a, b; Tauchi and Masland, 1984; Vaney, 1984) and contain the synthetic enzyme choline acetyltransferase (ChAT). In dissociated retinal cultures, ChAT was demonstrated in presumptive amacrine cells using a monoclonal mouse anti-rat antibody. Figure 10 shows a cell in culture for $1 \mathrm{~d}$ that has been stained with this ChAT antibody using the PAP method. ChAT-positive cells in these cultures often had a myriad of small neurites; these processes often grew to several hundred microns over the course of a few days.

\section{Biochemical evidence for endogenous ACh in cultures}

The experiment to measure the amount of ACh spontaneously released into the culture fluid was performed in triplicate on dishes from platings in which electrophysiological evidence (see above) also suggested the presence of endogenous $\mathrm{ACh}$. Although the previous patch-clamp experiments had been performed in the absence of an anticholinesterase, because of the long incubation period necessary to measure the ${ }^{3} \mathrm{H}-\mathrm{ACh}$ biochemically, neostigmine was used to prevent hydrolysis of the $\mathrm{ACh}$ released into the medium. The radiolabeled-precursorloading technique, corrected for specific activity, demonstrated that $\mathrm{ACh}$ was present in the culture medium of the retinal cells at a concentration of $0.45 \pm 0.11 \mathrm{~nm}$. Local pools next to amacrine cells would be expected to have significantly higher concentrations of $\mathrm{ACh}$. For example, at the low plating densities used in this experiment, there were about $10 \mathrm{ChAT}$-positive cells per dish (determined from ChAT staining as described above). An approximate calculation of the steady-state concentration of $\mathrm{ACh}$ created by a point source diffusing into an infinite reservoir (e.g., an unbounded sphere) can be made using

$C=[q / 4 \pi D r][\operatorname{erfc}(r / 2 \vee(D t))] \quad$ (Equation 3.5b, Crank, 1956)

where $C$ is the concentration in the steady-state, $q$ is the rate per second of production of the diffusing substance $\left(2 \times 10^{5}\right.$ molecules/sec for each of $10 \mathrm{ChAT}$-positive cells calculated from the total concentration in the culture medium), $D$ is the diffusion coefficient (assumed to be on the order of $10^{-5} \mathrm{~cm}^{2} / \mathrm{sec}$ ), $r$ is the distance from the point source, and $t$ is time (infinite in the steady state). At effectively infinite time (steady state), the equation simplifies to $C=[q / 4 \pi D r]$, which is multiplied by a factor of 2 to approximate diffusion into a hemisphere from a cell on the bottom of a culture dish. This calculation results in a concentration of $500 \mathrm{nM} \Lambda \mathrm{Ch}$ at a distance of $10 \mu \mathrm{m}$ from a ChATpositive cell. Taken together with the physiology experiments described earlier and in a previous report (Lipton et al., 1987), this concentration seems a reasonable one to cause a constant (nondesensitizing) activation of the $\mathrm{ACh}$ receptors and therefore depolarization of ganglion cells located near amacrines in more densely plated dishes.

To distinguish quantal from nonquantal release, the biochemical measurement of endogenous ACh was also attempted in the presence of extracellular cobalt ( $3 \mathrm{~mm}$ ) or in high magnesium (nominally $20 \mathrm{~mm}$ ) and low calcium $(0.2 \mathrm{~mm}$ ) or in high calcium (15 mM). Within a few hours, however, these ionic changes affected the health or growth of the retinal cells (Lipton, 1986; Hahn et al., 1988), precluding comparison of these results with those obtained in the controls that were incubated in a more normal ionic milieu.

\section{Staining for $A C h E$ in retinal cultures}

Representative cultures $(n=24)$ were stained for AChE. Oneto three-day-old cultures were found to have very few AChEpositive cells (only $2-3$ cells per dish; $>2 \times 10^{5}$ total cells per dish). Interestingly, a few ganglion cells (cells co-labeled with granular blue dye) in addition to putative amacrine cells were 
A

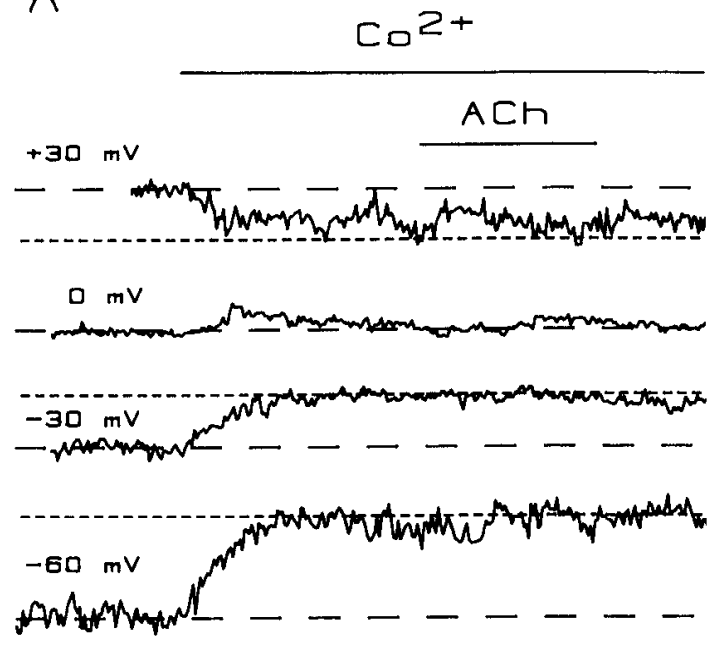

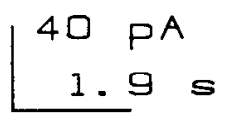

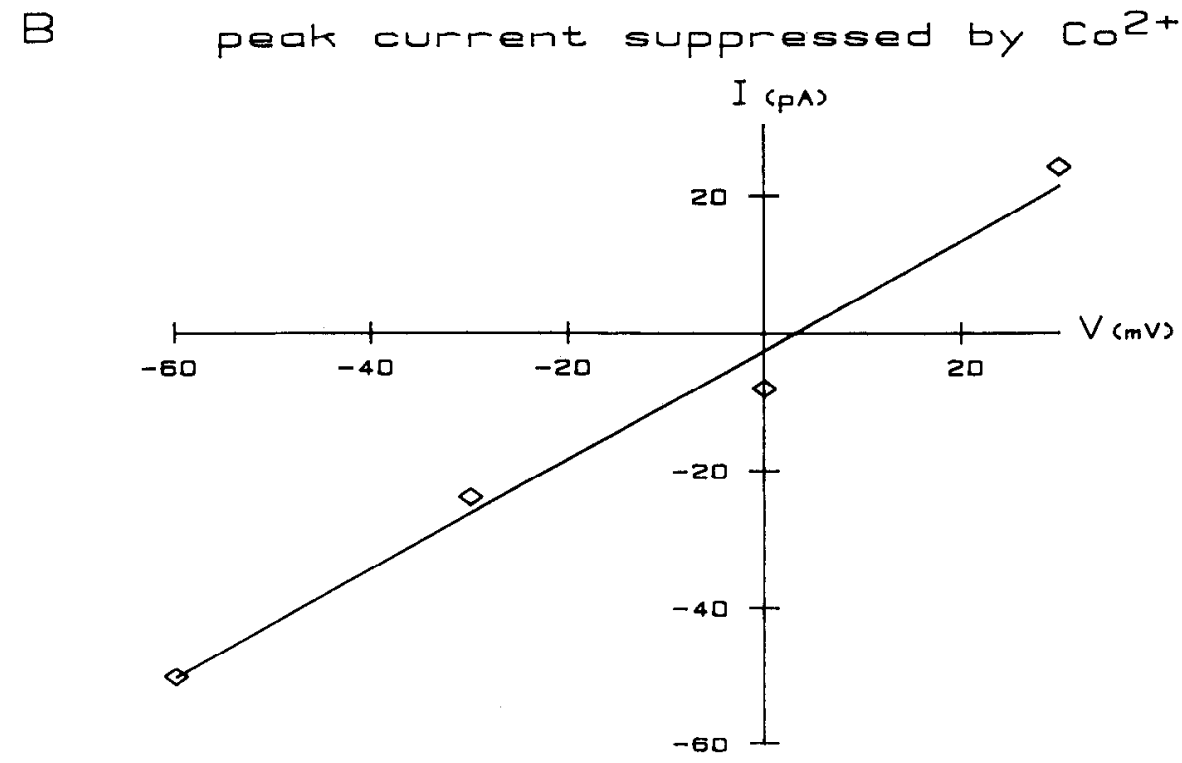

Figure 9. Effect of $\mathrm{Co}^{2+}$ during wholecell recording on a retinal ganglion cell exposed to tonic endogenous levels of $\mathrm{ACh}$ in the culture fluid. $A$, Retinal ganglion cell was locally microperfused with Hanks' solution containing $3 \mathrm{~mm} \mathrm{CoCl}{ }_{2}$ while varying the holding potential. During the peak current elicited by $\mathrm{Co}^{2+}$, the cell, which had previously responded to ACh in the absence of $\mathrm{CO}^{2+}$ (not shown), no longer responded to exogenous ACh. $B$, Peak currents in $A$ are plotted versus their holding potentials to produce an $I-V$ curve; the reversal potential was close to $0 \mathrm{mV}$. The bath contained the usual saline based upon Hanks' salts; in the pipette solution, Cs aspartate $(120 \mathrm{~mm})$ and $\mathrm{TEACl}(20 \mathrm{mM})$ were substituted for $\mathrm{KCl}$. found to be positive for AChE. Of note, the extremely low activity of $\mathrm{AChE}$ in these retinal cultures is similar to the level found previously in young nerve-muscle cultures (Weldon et al., 1981), which also proved to harbor endogenous levels of ACh (Sun and Poo, 1985). The fact that the surface AChE had not yet attained high activity in these cultures may in part account for the tonic presence of unhydrolyzed $\mathrm{ACh}$.

\section{Discussion}

Both the electrophysiological and the biochemical experiments in the present study are consistent with the notion that there was tonic release of endogenous ACh in a set of retinal cultures. These cultures were plated densely $\left(>2 \times 10^{5}\right.$ cells) and were grown in a particular batch of rat serum. It makes sense that plating the retinal cells densely increased the number of cholin- ergic amacrine cells per dish and thus the amount of ACh released into the culture fluid; the reason that endogenous $\mathrm{ACh}$ levels were more often found when a specific batch of rat serum was used is not, however, apparent at this time. Whatever the mechanism, the low levels of $\mathrm{ACh}$ released into the cultures were sufficient to influence the electrical properties of those ganglion cells located near the cholinergic amacrine cells that were apparently responsible for the presumed leakage. The concept of spontaneous release of ACh neurotransmitter in cultures is novel for the mammalian CNS, and for the retina in particular, but is not entirely new and, in fact, has a clear precedent in that similar results have been obtained in developing nerve-muscle cultures (Hume et al., 1983; Young and Poo, 1983; Sun and Poo, 1985; Xie and Poo, 1986).

The application by pressure pipette of $\mathrm{ACh}, \mathrm{dTC}$, or $\mathrm{Dh} \beta \mathrm{e}$ 


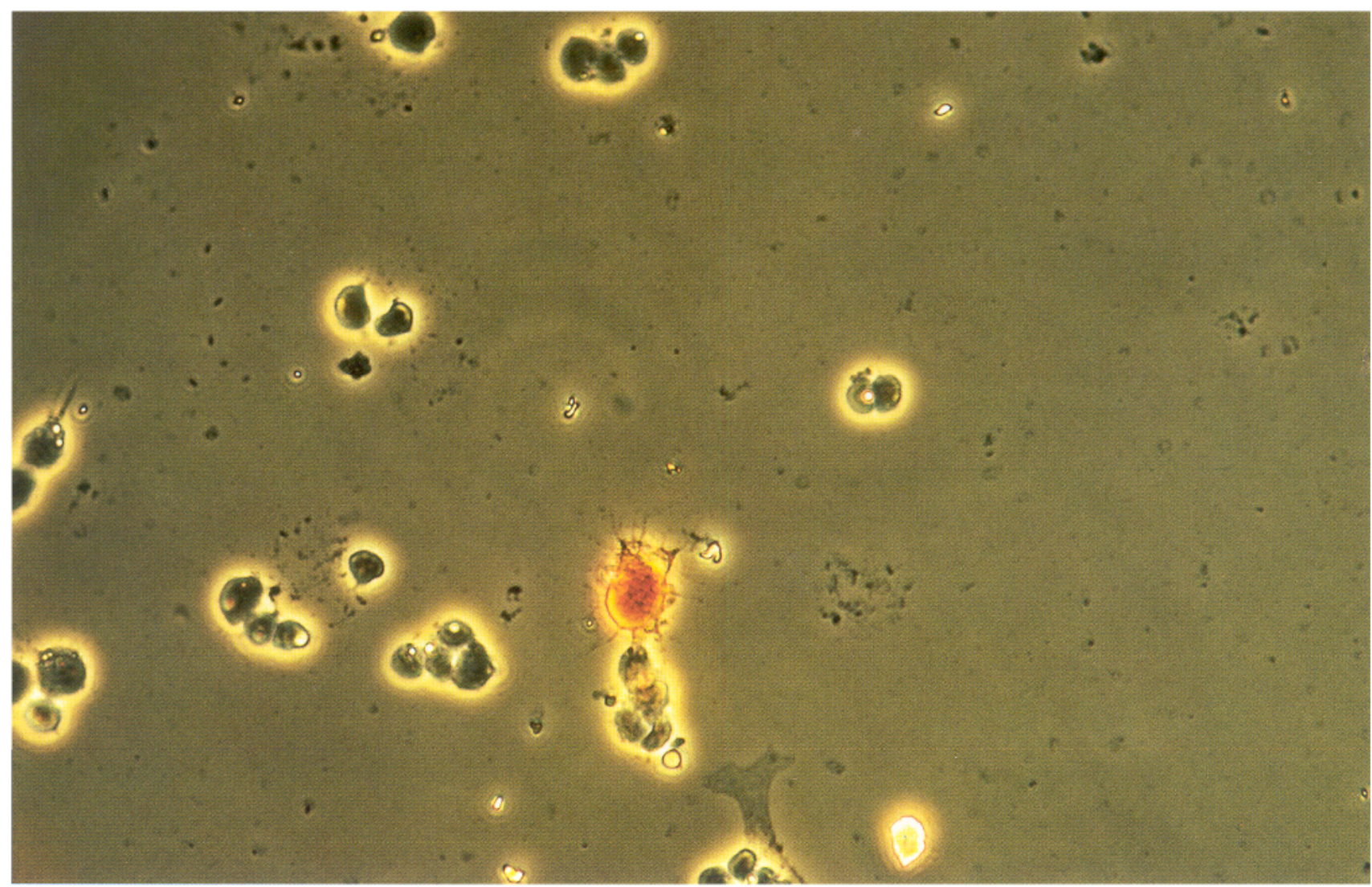

Figure 10. Labeling choline acetyltransferase-positive cells in rat retinal cultures. A mouse anti-rat monoclonal antibody against ChAT was used to stain putative cholinergic amacrine cells using the PAP technique (see Materials and Methods). Note the myriad of small processes emanating from this cell that has been in culture for $18 \mathrm{hr}$. The labeled cell is an orange-brown color, in contrast to the blue-green background of unlabeled cells.

to retinal ganglion cells in these cultures resulted in an apparent outward current that varied in magnitude from a few picoamperes to (very rarely) $100 \mathrm{pA}$, with a median value of about 15 pA. Since the mean input resistance of the ganglion cells is on the order of a gigaohm (Lipton and Tauck, 1987), this current would result in a depolarization of equal magnitude in millivolts, e.g., a $15 \mathrm{pA}$ outward current would produce a $15 \mathrm{mV}$ depolarization. In a few cells this prediction was directly verified during current-clamp recordings. These findings imply that the retinal ganglion cells that display an outward current response to ACh while voltage-clamped to negative holding potentials are normally tonically depolarized in the culture dish. In the future, current-clamp recordings comparing the resting potentials of large numbers of ganglion cells under different culture conditions should be able to verify this hypothesis.

Can we attribute the ACh-, nicotine-, carbachol-, dTC-, and $\mathrm{Dh} \beta \mathrm{e}$-induced outward currents at negative holding potentials soley to the blockage of neural nicotinic receptors? For example, in other systems dTC can act as a partial agonist; could this effect be contributing here? If dTC were a partial agonist in this setting, an inward rather than an outward current at negative voltages would have been observed. Furthermore, it is unlikely that other actions of these drugs not related to their nicotinic effects would all produce the same phenomenon. Based upon the similarity of the drug-evoked responses, it appears likely that these substances were all influencing the same ionic current. Finally, the observation was made that the conductance de- creased during the apparent outward current, and, thus, this current was really a decrease in a tonic inward current. Since all of these agents have the common property of affecting nicotinic currents, these findings are most consistent with the notion that the tonic inward current was nicotinic in nature. The $I-V$ relation of the current suppressed by ACh (Fig. 6) supports this view.

Taken together, the electrophysiological and biochemical data suggest that the criteria of retinal cultures having an endogenous release of ACh should consist of one or more of the following: (1) the presence of an apparent outward current at negative holding potentials in response to $\mathrm{ACh}$, nicotine, carbachol, dTC, or $\mathrm{Dh} \beta \mathrm{e} ;(2)$ the activation of nicotinic channels in ouside-out patches of muscle used as "detector" pipettes in the culture; (3) the finding that $\mathrm{AChE}$ makes previously unresponsive ganglion cells become responsive to the exogenous application of $\mathrm{ACh}$ or another nicotinic agonist; or (4) the direct measurement of $\mathrm{ACh}$ in the culture fluid at a mean level on the order of $0.5 \mathrm{nM}$ or higher.

The finding that $\mathrm{ACh}$ is tonically released in retinal cultures shows a remarkable similarity to results obtained in the intact mammalian retina. Masland and colleagues $(1984,1987)$ have demonstrated, in addition to light-evoked release, a nonquantal leak of $\mathrm{ACh}$ from the intact rabbit retina. In order to determine if the endogenous level of ACh in the retinal cultures was secondary to a nonquantal leakage, experiments using (1) extracellular cobalt $(3 \mathrm{mM}),(2)$ high extracellular magnesium (nom- 
inally $20 \mathrm{~mm}$ ) and low calcium (0.2 mm) (Lipton, 1986), or (3) high extracellular calcium (15 mM; Vyskocil et al., 1983) were attempted. The first 2 of these procedures block quantal release, while the third inhibits nonquantal leakage in other preparations (Sun and Poo, 1985). Unfortunately, control experiments revealed that these various manipulations had other effects on the growth or survival of the ganglion cells (Lipton, 1986; Hahn et al., 1988; S. A. Lipton, unpublished observations) so they could not be used in this context. Thus, although the tonic release of ACh from the intact retina has been shown to represent most likely a nonquantal leakage (Masland and Cassidy, 1987), the mechanism of release in retinal cultures remains a question for future studies. Nevertheless, we believe that the release of $\mathrm{ACh}$ in the cultures represents nonquantal leakage since this not only occurs in the intact retina but produces a very large spontaneous leak of $\mathrm{ACh}$ which is maintained in the presence of high $\mathbf{M g}^{2+}$ (Masland and Cassidy, 1987). Also, a similar nonquantal leakage of $\mathrm{ACh}$ has been observed at the intact neuromuscular junction and in nerve-muscle cultures (Katz and Miledi, 1977; Sun and Poo, 1985). In contrast to the intact retina, the culture system described here offers more precisely controlled conditions for the experimental manipulation of the system in order to investigate the effects and the significance of this tonic release of ACh (Lipton et al., 1988).

$\mathrm{ACh}$ has been suggested to be a trophic factor in the mammalian CNS, as well as at the neuromuscular junction (Drachman, 1974; Gutmann, 1977; Katz and Miledi, 1977; Pestronk et al., 1980; Bray et al., 1982; Bear and Singer, 1986; Xic and Poo, 1986). The retinal cultures of the present study will be a useful system for the future study of the trophic action of ACh in the mammalian CNS, specifically the effect of $\mathrm{ACh}$ on process outgrowth and regeneration (Frosch et al., 1986; Lipton et al., 1988). The influence of the spontaneous release of $\Lambda \mathrm{Ch}$ on the developing synapses in culture between cholinergic amacrine and ganglion cells may also help to elucidate trophic interactions between neurons and their targets during synaptogenesis. Since similar release of $\mathrm{ACh}$ occurs in the intact retina and in cultures, these studies may reflect normal homeostatic mechanisms.

In summary, a spontaneous release of ACh could be observed in many retinal cultures, resembling to some degree the leakage found in the intact retina. This tonic release can be studied in the culture system using patch-clamp methods in the absence of anticholinesterase. The biochemical measurement of ${ }^{3} \mathrm{H}-\mathrm{ACh}$, however, required several hours of incubation; therefore, anticholinesterase treatment was used to prevent the breakdown of ACh. The culture system allows the precise control of the extracellular environment and will thus be helpful in determining the mechanism as well as the role of the spontaneous release of $\mathrm{ACh}$ in the retina.

\section{References}

Adams, D. J., T. M. Dwyer, and B. Hille (1980) The permeability of endplate channels to monovalent and divalent cations. J. Gen. Physiol. 75: 493-510.

Ariel, M., and N. W. Daw (1982a) Effects of cholinergic drugs on receptive field properties of rabbit retinal ganglion cells. J. Physiol. (Lond.) 342: 135-160.

Ariel, M., and N. W. Daw (1982b) Pharmacological analysis of directionally sensitive rabbit retinal ganglion cells. J. Physiol. (Lond.) 324: $161-185$.

Bear, M. F., and W. Singer (1986) Modulation of visual cortical plasticity by acetylcholine and noradrenaline. Nature 320: 172-176.

Bray, J. J., J. W. Forest, and J. I. Hubbard (1982) Evidence for the role of non-quantal acetylcholine in the maintenance of the membrane potential of rat skeletal muscle. J. Physiol. (Lond.) 326: 285-296.

Caldwell, P. C. (1970) Calcium chelation and buffers. In $A$ Symposium on Calcium and Cellular Function, A. W. Cuthbert, ed., St. Martin's Press, New York.

Crank, J. (1956) The Mathematics of Diffusion, Oxford University Press. London, p. 30.

Delfs, J. R., C.-H. Zhu, and M. A. Dichter (1984) Coexistence of acetylcholinesterase and somatostatin-immunoreactivity in neurons cultured from rat cerebrum. Science 223: 61-63.

Drachman, D. B. (1974) Trophic functions of the neuron. Ann NY. Acad. Sci. 228: 1-143.

Famiglietti, E. V., Jr. (1983) On and off pathways through amacrine cells in mammalian retina: The synaptic connections of "starburst" amacrine cells. Vision Res. 23: 1265-1281.

Fenwick, E. M., A. Marty, and E. Neher (1982) A patch-clamp study of bovine chromaffin cells and their sensitivity to acetylcholine. $\mathbf{J}$. Physiol. (Lond.) 331: 577-597.

Frosch, M. P., M. D. Phillips, E. Aizenman, D. L. Tauck, and S. A. Lipton (1986) Nicotinic cholinergic blocking agents enhance process outgrowth by solitary rat retinal ganglion cells in culture. Soc. Neurosci. Abstr. 12: 1505.

Furshpan, E. J., S. C. Landis, S. G. Matsumoto, and D. D. Potter (1986) Synaptic functions in rat sympathetic neurons in microcultures. I. Secretion of norepinephrine and acetylcholine. J. Neurosci. 6: 10611079.

Gutmann, E. (1977) Trophic effects in nerve-muscle cell relations. In Synapses, G. A. Cotrell and P. N. R. Usherwood, eds., Academic Press, New York.

Hahn, J. S., E. Aizenman, and S. A. Lipton (1988) Central mammalian neurons normally resistant to glutamate toxicity are made sensitive by elevated extracellular $\mathrm{Ca}^{2+}$; toxicity blocked by the NMDA antagonist MK-801. Proc. Natl. Acad. Sci. USA (in press).

Hamill, O. P., and B. Sakmann (1981) Multiple conductance states of single acetylcholine receptor channels in embryonic muscle cells. Nature 294: 462-464.

Hamill, O. P., A. Marty, E. Neher, B. Sakmann, and F. J. Sigworth (1981) Improved patch-clamp techniques for high resolution current recording from cells and cell-free membrane patches. Pfluegers Arch. 391: $95-100$.

Hildebrand, J. G., D. L. Barker, E. Herbert, and E. A. Kravitz (1971) Screening for neurotransmitters: A rapid radiochemical procedure. J. Neurobiol. 2: 231-256.

Hume, R. L., and M. G. Honig (1986) Excitatory action of ATP on embryonic chick muscle. J. Neurosci. 6: 681-690.

Hume, R. L., L. W. Role, and G. D. Fischbach (1983) Acetylcholine release from growth cones detected with patches of acetylcholine receptor-rich membranes. Nature 305: 632-634.

Katz, B., and R. Miledi (1977) Transmitter leakage from motor nerve endings. Proc. R. Soc. London [Biol.] 196: 59-72.

Koelle, G. B. (1954) The histochemical localization of cholinesterase in the central nervous system of the rat. J. Comp. Neurol. 100: 211228.

Leifer, D., S. A. Lipton, C. J. Barnstable, and R. H. Masland (1984) Monoclonal antibody to Thy-1 enhances regeneration of processes by rat retinal ganglion cells in culture. Science 224: 303-306.

Lipton, S. A. (1986) Blockade of electrical activity promotes the death of mammalian retinal ganglion cells in culture. Proc. Natl. Acad. Sci. USA 83: 9774-9778.

Lipton, S. A., and D. L. Tauck (1987) Voltage-dependent conductances of solitary ganglion cells dissociated from the rat retina. J. Physiol. (Lond.) 385: 361-391.

Lipton, S. A., A. Aizenman, and R. H. Loring (1987) Neural nicotinic acetylcholine responses in solitary mammalian retinal ganglion cells. Pfluegers Arch. 410: 37-43.

Lipton, S. A., M. P. Frosch, M. D. Phillips, D. L. Tauck, and E. Aizenman (1988) Nicotinic cholinergic blocking agents enhance process outgrowth by solitary rat retinal ganglion cells in culture. Science 239 : 1293-1296.

Masland, R. H., and A. Ames III (1976) Responses to acetylcholine of ganglion cells in an isolated mammalian retina. J. Neurophysiol. 39: $1220-1235$.

Masland, R. H., and C. Cassidy (1987) The resting release of acetylcholine by a retinal neuron. Proc. R. Soc. London [Biol.] 232: 227238.

Masland, R. H., and Livingstone, C. J. (1976) Effect of stimulation 
with light on synthesis and release of acetylcholine by an isolated mammalian retina. J. Neurophysiol. 39: 1210-1218.

Masland, R. H., J. W. Mills, and C. Cassidy (1984a) The functions of acetylcholine in the rabbit retina. Proc. R. Soc. London [Biol.] 223: 121-139.

Masland, R. H., J. W. Mills, and S. A. Hayden (1984b) Acetylcholinesynthesizing amacrine cells: Identification and selective staining by using radioautography and fluorescent markers. Proc. R. Soc. London [Biol.] 223: 79-100.

Massey, S. C., and M. Neal (1979) The light evoked release of acetylcholine from the rabbit retina in vivo and its inhibition by $\gamma$-aminobutyric acid. J. Ncurochem. 32: 1327-1329.

Mesulam, M.-M., and M. A. Dichter (1981) Concurrent acetylcholinesterase staining and $\gamma$-aminobutyric acid uptake of cortical neurons. J. Histochem. Cytochem. 29: 306-308.

Pestronk, A., D. B. Drachman, E. F. Stanley, D. L. Prince, and J. W. Griffin (1980) Cholinergic transmission regulates extrajunctional acetylcholine receptors. Exp. Neurol. 70: 690-696.

Puro, D. G., B.-A. Batelle, and K. E. Hansmann (1982) Development of cholinergic neurons of the rat retina. Dev. Biol. 91: 138-148.

Sun, Y.-A., and M.-M. Poo (1985) Non-quantal release of acetylcholine at a developing neuromuscular synapse in culture. J. Neurosci. 5: 634-642
Tauc, L. (1982) Nonvesicular release of neurotransmitter. Physiol Rev. 62: 857-893.

Tauchi, M., and R. H. Masland (1984) The shape and arrangement of the cholinergic neurons in the rabbit retina. Proc. R. Soc. London [Biol.] 223: 101-119.

Vaney, D. L. (1984) "Coronate" amacrine cells in the rabbit retina have a "starburst" dendritic morphology. Proc. R. Soc. London [Biol.] 203: 269-291.

Vyskocil, F., F. Nikolsky, and C. Edwards (1983) An analysis of the mechanisms underlying the non-quantal release of acetylcholine at the mouse neuromuscular junction. Neuroscience 9: 429-435.

Wcldon, P. R., F. Moody-Corbett, and M. W. Cohen (1981) Ultrastructure of sites of cholinesterase activity on amphibian embryonic muscle cells cultured without nerve. Dev. Biol. 84: 341-350.

Xie, S.-P., and M.-M. Poo (1986) Initial events in the formation of neuromuscular synapse: Rapid induction of acetylcholine release from embryonic neuron. Proc. Natl. Acad. Sci. USA 83: 7069-7073.

Yeh, H. H., B.-A. Batelle, and D. G. Puro (1983) Maturation of neurotransmission at cholinergic synapses formed in culture by rat retinal neurons: Regulation by cyclic AMP. Dev. Brain Res. 10: 63-72.

Young, S. H., and M.-M. Poo (1983) Spontaneous release of transmitter from growth cones of embryonic neurons. Nature 305: 634 637. 